\title{
Atmospheric Rivers in CMIP5 climate ensembles downscaled with a high resolution regional climate model
}

Matthias Gröger ${ }^{1}$, Christian Dieterich ${ }^{1}$, Cyril Dutheil ${ }^{1}$, H.E. Markus Meier ${ }^{1,2}$, Dmitry V. Sein ${ }^{3,4}$,

${ }^{1}$ Department of Physical Oceanography and Instrumentation, Leibniz Institute for Baltic Sea Research

5 Warnemünde, Rostock, 18119, Germany

${ }^{2}$ Research and Development Department, Swedish Meteorological and Hydrological Institute, Norrköping, 601

76, Sweden

${ }^{3}$ Shirshov Institute of Oceanology, Russian Academy of Sciences; Moscow, Russia

${ }^{4}$ Alfred Wegener Institute, Helmholtz Centre for Polar and Marine Research; Bremerhaven, Germany

10

Correspondence to: Matthias Gröger (matthias.groeger@io-warnemuende.de)

\section{Abstract}

Atmospheric rivers (AR) are important drivers of heavy precipitation events in western and central

15 Europe and often associated with intense floods. So far, the ARs response to climate change in Europe has been investigated by global climate models within the CMIP5 framework. However, their spatial resolution between 1 and $3^{\circ}$ is too coarse for an adequate assessment of local to regional precipitation patterns. Using a regional climate model with $0.22^{\circ}$ resolution we downscale an ensemble of 24 global climate simulations following the greenhouse gas scenarios RCP2.6, RCP4.5, RCP8.5.

The performance of the model was tested against ER-I reanalysis data. The downscaled simulation notably better represents small-scale spatial characteristics which is most obvious over the terrain of the Iberian Peninsula where the AR induced precipitation pattern clearly reflect eat-west striking topographical elements resulting in zonal bands of high and low AR impact. Over central Europe the model simulates a less far propagation of ARs toward eastern Europe compared to ERA-I but a higher share of AR forced heavy precipitation events especially Norway where $60 \%$ of annual precipitation maxima are related to ARs.

30 We find ARs more frequent and more intense in a future warmer climate especially in the higher emission scenarios whereas the changes are mostly mitigated under the assumption of RCP2.6. They also propagate further inland to eastern Europe in a warmer climate. In the high emission scenario RCP8.5 AR induced precipitation rates increase between 20 and $40 \%$ in western central Europe while mean precipitation rates increase by maximal $12 \%$. Over the Iberian Peninsula AR induced precipitation rates slightly decrease around $-6 \%$ but mean rates decrease around $-15 \%$. The result of these changes is an overall increased contribution of ARs to heavy precipitation with greatest impact over Iberia(15-30\%).

Over Norway average AR precipitation rates decline between -5 to $-30 \%$. These reductions most 40 likely the originate from regional dynamical changes. In fact, over Norway we find ARs originating from $>60^{\circ} \mathrm{N}$ are reduced by up to $20 \%$ while those originating south of $45^{\circ} \mathrm{N}$ are increased. Also, no clear climate change signal is seen for AR related heavy precipitation and annual maximum precipitation over Norway where the uncertainty of the ensemble is quite large. 


\section{Introduction}

45 Atmospheric rivers (ARs) are long and narrow corridors that transport large amounts of moisture from tropical and subtropical origin poleward (e.g. Zhu et al., 1998; Gimeno et al., 2014; Gimeno et al., 2016; Shields et al., 2019). Associated with intense precipitation they can be a strong contributor to the local groundwater inventory in regions prone to droughts and thus play an important role for the local water management (Lavers and Villarini, 2015; Gimeno et al., 2016), for example in dry areas of

50 the Middle East or North Africa (Massoud et al., 2020). On the other hand AR induced heavy precipitation can likewise cause tremendous economical damage due to flooding (e.g. Gimeno et al., 2016; Payne et al., 2020).

Due to their intense moisture load they play an important role for the global water cycle. It has been 5 estimated that ARs are responsible for $>90 \%$ of the meridional moisture transport through the midlatitudes (e,g. Gimeno et al., 2016, Gimeno et al., 2018). ARs are associated with extraordinary strong low level winds often positioned at the head of a cold front of extra-tropical storm systems (e.g. Dacre et al., 2015; Gimeno et al., 2016). Accordingly, they are modulated by large scale weather regimes as demonstrated by Pasquier et al. (2019). In the North Atlantic sector the moisture source

60 for ARs originates mainly from the subtropical Atlantic (Ramos et al., 2016). ARs can occur during the whole year but due to their strong linkage to extra-tropical storm systems they are more frequent during the cold season in the Northern Hemisphere (Lavers and Villarini 2013; Ramos et al., 2015).

In the North Atlantic and North Pacific Sectors of the World Ocean ARs have been identified as a big risk for heavy precipitation and flooding along the western coasts of California and Europe (e.g. Ralph et al., 2006; Neiman et al., 2011; Ralph and Dettinger, 2012; Lavers et al., 2011, Lavers et al., 2012; Lavers and Villarini; 2013; Ramos et al. 2015; Gao et al., 2016, Nayak et al., 2016; Nayak et al., 2017). In Europe flooding causes large amounts of economic damages which is expected to increase under climate warming (Ashley et al., 2005; Sayers et al., 2015; Alfieri et al., 2016). Therefore, it is

70 essential to investigate mechanisms that rise the risk for floods (e.g. Kouski 2014; Alfieri et al., 2018). For Europe a significant role of ARs in heavy precipitation events and flooding has been demonstrated by previous studies. Lavers and Villarini (2013) analyzed atmospheric reanalysis data sets and found up to 8 out of the 10 annual maximum precipitation events to be related to ARs during the period 1979-2011. Besides their potential to force flooding ARs can contribute significant amounts

75 of precipitation to the annual total precipitation especially in semi-arid regions and thus can be an important source to the local water inventory in regions often threatened by droughts (e.g. Laver and Villarini, 2015; Ramos et al., 2016; Gimeno et al., 2016). In Europe most damages associated with ARs are located along the western continental margins in particular over the Iberian Peninsula, the United Kingdom (UK) and Scandinavia (Laver et al. 2013, Ramos et al., 2015; Whan et al., 2020).

80 However they also can penetrate far inland and produce heavy rainfall events as far east as in Germany and Poland (Lavers and Villarini, 2013).

Because of the larger water holding capacity of a warmer atmosphere it has been suggested that climate warming will increase the risk for intense flooding (e.g. Held and Soden ,2006). Lavers et al.

85 (2015) demonstrated that the intensification of the global water cycle due to climate warming strengthens the mean atmospheric water transports over the North Atlantic by $30-40 \%$. So far, assessments of AR related flood risk in a future warmer climate are primarily based on climate projections from global climate models (e.g. Lavers et al., 2013; Lavers et al., 2015; Warner et al., 2015, Ramos et al., 2016; Gao et al., 2016; Espinoza et al., 2018; Whan et al., 2020). Lavers et al.

90 (2013) showed an intensification of AR in terms of frequency and intensity in future climate based on the analysis of five CMIP5 global models. Ramos et al. (2016) found a doubling of AR frequency together with an increase of moisture load in the RCP4.5 and RCP8.5 scenarios in six CMIP5 models at the end of the $21^{\text {st }}$ century compared to the historical period. Gao et al. (2016) analyzed an 
ensemble of 24 CMIP5 global models and found a pronounced increase in the contribution of AR related precipitation to the total annual precipitation in a future warmer climate following the RCP8.5 scenario. Whan et al. (2020) recently used the high resolution version of the CMIP5 EC-Earth model to study the climate change impact on AR induced precipitation over Norway. They indicated that up to $80 \%$ of the winter maximum precipitation is associated with ARs. They also found the magnitude of extreme precipitation events to be mainly controlled by AR intensity.

\section{Purpose of this study}

The majority of global models currently employed in the CMIP5 and CMIP6 framework employed provide a resolution typically ranging from $1.4^{\circ}$ to $3^{\circ}$ allowing a robust analysis of the large scale

105 impact on continental scale precipitation. However, they do not fully resolve small scale characteristics which is necessary to assess the local impact on AR related precipitation patterns. Here, we investigate how far downscaled high resolution regional projections can improve the representation of ARs on the regional scale and thus add value to global assessments. For Europe such regional assessments are still lacking. Here we analyze for the first time a regional

110 climate ensemble for Europe based on a horizontal resolution of $0.22^{\circ}$. We use this ensemble to analyze future changes in AR frequency and AR induced heavy precipitation pattern over Europe and their implication for the local water budget. We likewise aim to assess climate induced changes in the regional pathways of ARs on their journey across Europe. Finally, we assess uncertainties with respect to 3 different climate scenarios (RCP2.6, RCP4.5,RCP8.5) and 9 different global climate

115 models from the CMIP5 suite.

The paper is outlined as followed: Section 2 briefly describes the regional climate model RCA-NEMO as well the AR detection procedure. Section 3 provides a validation RCA historical ensemble with respect to ARs for the present-day period and investigates the added value of high resolution. Section

1204 analyzes future changes in AR frequencies and the impact on precipitation under different climate scenarios. Section 5 discusses uncertainties with respect to the choice of the driving global model. Main conclusions are summarized in section 6.

\section{Methods}

125 2.1.The regional climate model RCA-NEMO

The regional climate model (Wang et al., 2015; Gröger et al., 2015; Dieterich et al., 2019) consists of the Rossby Center regional atmosphere model RCA (Samuelsson et al., 2011; Kupiainen et al., 2014) version 4 coupled to the Ocean General Circulation model NEMO (Table 1, Nucleus for European

130 Modelling the Ocean NEMO, Madec, 2012). RCA is a hydrostatic atmosphere model which is set up for this study according to the Euro-Cordex domain (Fig. 1). The horizontal resolution is 0.22 degrees on a rotated grid yielding grid cell sizes between $550-600 \mathrm{~km}^{2}$ (Table 1) and the vertical discretization is given by 40 hybrid levels. At the lateral boundaries the model is driven by data from either reanalysis data sets or global climate model output. The forcing data are prescribed at 6-hourly

135 time intervals. The land surface boundary is prescribed by ECOCLIMAP (Champeaux et al., 2005)and used to calculate the land - air mass and energy fluxes. Different to the majority of the EURO-Cordex high resolution ensembles (Jacob et al., 2014), RCA is interactively coupled to the 3D ocean model NEMO. The coupling area comprises the North Sea and the Baltic Sea. Over this region sea ice temperature, sea ice fraction, sea ice albedo, and water temperature is explicitly modeled by NEMO

140 and communicated at 3-h time steps to RCA. Air - sea mass and energy fluxes are then calculated in the atmosphere model and used to drive NEMO which is set up in a resolution of 2 nautical miles $(\sim 3.7 \mathrm{~km})$ and 56 vertical varying $z^{*}$ layers. The coupling is managed by the OASIS coupler (Valcke et 
al., 2003). Outside the coupled domain, i.e. the Mediterranean and the North Atlantic, RCA is driven by reanalyses data in the hindcast case or by global climate model output. Sea ice fields are explicitly modeled by the Louvain-la-Neuve sea ice model LIM3 (Vancoppenolle et al., 2008).

\begin{tabular}{|c|c|c|c|c|c|c|}
\hline Model system & $\begin{array}{c}\text { Atmosphere } \\
\text { component }\end{array}$ & $\begin{array}{c}\text { Ocean } \\
\text { component }\end{array}$ & $\begin{array}{c}\text { Domain size } \\
\text { Atmosphere }\end{array}$ & $\begin{array}{c}\text { Domain size } \\
\text { ocean model }\end{array}$ & $\begin{array}{c}\text { Grid resolution } \\
\text { atmosphere }\end{array}$ & Vertical levels \\
\hline RCA-NEMO & RCA & NEMO3.3.1 & Euro-Cordex & $\begin{array}{c}\text { North Sea, } \\
\text { Baltic Sea }\end{array}$ & $550-600 \mathrm{~km}^{2}$ & 40 \\
\hline ERAI & IFS (Cy31r2) & $\begin{array}{c}\text { Prescribed } \\
\text { SSTs }\end{array}$ & global & global & $6400 \mathrm{~km} 2$ & 60 \\
\hline
\end{tabular}

Table 1: Climate model configuration employed in this study. Also shown is the analyzed data set from the ERAI reanalysis

RCA-NEMO has been intensively validated and comprehensively described in detail (e.g. Wang et al., 2015; Gröger et al., 2015; Dieterich et al., 2019; Gröger et al., 2019; Gröger etal., 2021a). It has been employed in large ensembles to study the present climate and to simulate the mean response to global climate change by downscaling global climate scenarios in a huge ensemble (Dieterich et al., 2019; Gröger et al., 2019; Gröger et al., 2021a). Gröger et al. (2021a) showed that the RCA-NEMO coupled ensemble is well within the range of the high resolution Euro-Cordex ensemble (Jacob et al., 2014). However, significant differences arise over interactively coupled areas over sea (Gröger et al., 2021a; Gröger et al., 2021b). This applies to both climatic mean changes, as well as climatic extremes (e.g. dry periods cold spells, heat waves etc).

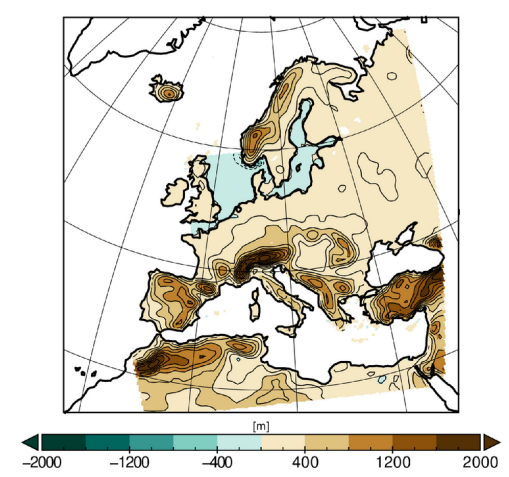

Figure 1: Model domain showing the topgraphy of the RCA-NEMO climate model. Bathymetricy information indicates the domain of the interactively coupled ocean model NEMO.

\subsection{The high resolution ensemble}

The above described model was used to downscale a suite of global model climate scenarios taken from the Coupled Model Intercomparison Project phase 5 (CMIP5, Taylor et al., 2012). Table 2 lists the individual realizations and primarily distinguishes the applied scenarios (first row) and individual model configurations (first column). In addition to the used global climate models we also analyze a hindcasst simulation forced by ERA-I reanalysis data to validate the model for the present day climate (1979-2009) of the ensemble is provided by RCA which comprises 34 runs including one ERAI 


\begin{tabular}{|l|l|l|l|l|}
\hline Reg.Mod - Glob. model & historical & RCP2.6 & RCP4.5 & RCP8.5 \\
\hline RCA - MPI-ESM-LR & $\mathrm{x}$ & $\mathrm{x}$ & $\mathrm{x}$ & $\mathrm{x}$ \\
\hline RCA - EC-EARTH & $\mathrm{x}$ & $\mathrm{x}$ & $\mathrm{x}$ & $\mathrm{x}$ \\
\hline RCA - HadGEM2-ES & $\mathrm{x}$ & $\mathrm{x}$ & $\mathrm{x}$ & $\mathrm{x}$ \\
\hline RCA - IPSL-CM5A-MR & $\mathrm{x}$ & & $\mathrm{x}$ & $\mathrm{x}$ \\
\hline RCA - GFDL-ESM2M & $\mathrm{x}$ & $\mathrm{x}$ & $\mathrm{x}$ & $\mathrm{x}$ \\
\hline RCA - CanESM2 & $\mathrm{x}$ & & $\mathrm{x}$ & $\mathrm{x}$ \\
\hline RCA - CNRM-CM5 & $\mathrm{x}$ & & $\mathrm{x}$ & $\mathrm{x}$ \\
\hline RCA - NorESM1-M & $\mathrm{x}$ & $\mathrm{x}$ & $\mathrm{x}$ & $\mathrm{x}$ \\
\hline RCA - MIROC5 & $\mathrm{x}$ & $\mathrm{x}$ & $\mathrm{x}$ & $\mathrm{x}$ \\
\hline RCA - ERAI & $\mathrm{x}$ & & & \\
\hline
\end{tabular}

Table 2: List of 34 coupled regional simulations grouped by greenhouse gas scenarios and downscaled global models.

The chosen climate scenarios follow the protocol of Representative Concentration Pathways (RCP) used in CMIP5 and comprise three different greenhouse gas assumptions. One low emission scenario assumes vigorous mitigation actions (RCP2.6 van Vuuren et al. 2007, 2011) and was developed in regard to limit the global mean temperature to $2{ }^{\circ} \mathrm{C}$ warming since the pre-industrial period. It

175 assumes negative emission during the last decade of the $21^{\text {st }}$ century. RCP4.5 is a moderate scenario where emissions peak at the mid-century (2040) and are kept constant after $\sim 2080$ at a value about half of the value at the end of the historical period (Clarke et al. 2007; Thomson et al. 2011). Finally, a totally unmitigated scenario RCP8.5 (Riahi et al. 2007; Riahi et al., 2011) assumes rising emissions up to the end of the century. The three scenarios impose a maximal radiative forcing of $2.6,4.5$, and

$1808.5 \mathrm{~W} / \mathrm{m} 2$ compared to pre-industrial conditions.

\subsection{Detection of atmospheric rivers}

The detection procedure of ARs is briefly described below and was performed for 30 year periods at

the end of the $20^{\text {th }}$ century (1970-1999) and at the end of the $21^{\text {st }}$ century (2070-2099) i.e. for each of the RCP2.6, RCP4.5, and RCP8.5 individually. Only the RCA-ERAI hindcast run was done for 1979 to 2009.

Atmospheric river detection can be basically done using their specific characteristics, namely the 190 extraordinary moisture transport and their elongated shape (width and length scales). A number of studies addressed methods to detect ARs in model simulations and gridded reanalysis data (Lavers et al., 2011; Lavers et al., 2012; Nayak et al., 2014; Nayak and Villarini, 2016; Gao et al., 2015; O'Brian et al., 2020). An overview can be found in Guan and Waliser (2015). We here employ the detection algorithm developed by Laver et al. (2012) and Lavers and Villarini (2013) which has been

195 successfully applied both for hindcast simulations and climate studies (Lavers and Villarini, 2012; Lavers et al., 2013). First, the vertically Integrated atmospheric water Vapor Transport (hereafter IVT) is calculated at every model output time step. The vertical integration is done over the models pressure levels from 1000 to $300 \mathrm{hPa}$ that were converted from the models hybrid levels: 


$$
I V T=\sqrt{\left(\frac{1}{g} \int_{1000}^{300} q u d p\right)^{2}+\left(\frac{1}{g} \int_{1000}^{300} q v d p\right)^{2}}
$$

where $g$ is gravitational acceleration, $q$ is specific humidity $\mathrm{kg} / \mathrm{kg}, u$ and $v$ the horizontal wind components and $d p$ the pressure level difference of adjacent pressure levels. In the two hydrostatic models' hybrid level space, the IVT is balanced by precipitation minus evaporation.

Then the $85^{\text {th }}$ percentile IVT is calculated based on IVTs at 12:00 UTC time stamps and along $10^{\circ} \mathrm{W}$ longitude (Lavers and Villarini 2012; Lavers et al. 2013). Following Lavers et al. (2013) this procedure is done for meridional bins of $5^{\circ}$ between $35-70^{\circ} \mathrm{N}$. The resulting 85 th percentile values served then as threshold for the detection of ARs (Fig. 2). After this pre-processing all 6-hour IVT fields are analyzed along $10^{\circ} \mathrm{W}$ and the $5^{\circ}$ latitudinal bins at every single output time step. If the max IVT within an individual bin exceeded the threshold for that bin (Fig. 2) a westward and eastward search was done starting from $10^{\circ} \mathrm{W}$ to $30^{\circ} \mathrm{W}$ and $25^{\circ} \mathrm{E}$. All grid cells where the threshold was exceeded were retained (Lavers and Villarini, 2013).
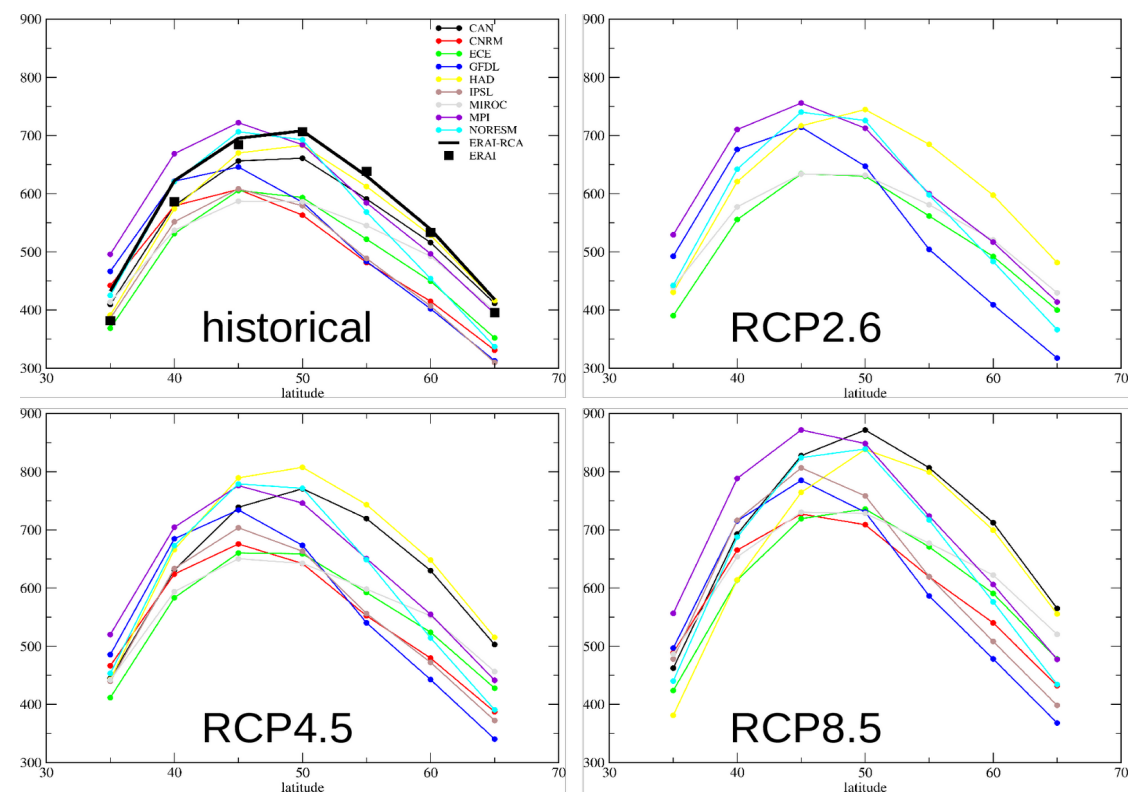

Figure 2: IVT thresholds [ $\left.\mathrm{kg} \mathrm{m}^{-1} \mathrm{~s}^{-1}\right]$ for the ensembles' historical period (1970-1999, upper left) and RCP climate scenarios (2070-2099) at $10^{\circ} \mathrm{W}$ used by the algorithm to track ARs..

Next, the resulting fields are further evaluated for spatial and temporal criteria (Lavers and Villarini, 2013). Hence the axis of a potential AR was determined as maximum along each longitude IVT of the structure. Only those fields were retained with an axis longer than $1500 \mathrm{~km}$ and then classified as AR. Furthermore, an AR has to be persistent over a period of at least 18 hours. Figure 3 shows a prominent example for an AR detected in the ERA-I reanalysis (left) and the ERA-I hindcast simulation (right) that demonstrably caused intense rain over Europe (Lavers and Villarini, 2013). The 
whole detection procedure is performed separately for the historical and future periods and for each of the ensemble members respectively (Table 2 ).

225

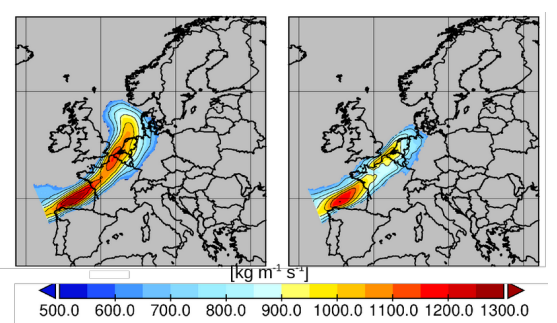

Figure 3: Atmospheric river associated with storm Lothar detected in the ERA-I reanalysis (left) and the ERA-I hindcast simulation (right), 25 December, 1999; 0:00:00 UTC. IVT values below the threshold are masked out.

\section{ARs in the historical climate}

\subsection{General statistics}

230 Table 3 summarizes the frequency of atmospheric rivers (expressed as total ARs detected in a 30 year period and along $10^{\circ} \mathrm{W}$ ) for each run of the ensemble as well as from the ERAI reanalysis data set and the hindcast run. The number of detected ARs in the RCA-ERAI hindcast (322) is nearly identical with that analyzed from the ERAI reanalysis (321) itself which was used to drive the model. This indicates that the number of ARs in RCA is primarily controlled by the lateral boundary

235 conditions. This is not surprising since ARs develop in open ocean regions far outside the model domain and so the potential for alterations by the regional model is quite low. According to this, the number of detectable ARs in the individual RCA historical climate simulations (Table 3) will likewise reflect the ARs generated from the driving global climate model. Consequently, the RCA historical climate ensemble exhibits a fairly large spread during the historical period ranging from 262 (RCAMIROC) to 421 (RCA-NORESM). The difference between the ensemble mean of RCA historical simulations (RCA-MEAN=359) and the RCA-ERAI hindcast run $(n=322)$ is quite low compared to the standard deviation over the RCA historical ensemble (58). 


\begin{tabular}{|l|l|l|l|l|}
\hline & $\begin{array}{l}\text { HISToricall } \\
\text { Hindcast }\end{array}$ & RCP26 & RCP45 & RCP85 \\
\hline RCA-ERAI & 322 & & & \\
\hline ERAI reanalysis & 321 & & & \\
\hline \multicolumn{5}{|c|}{ RCA-NEMO climate ensemble } \\
\hline RCA-MEAN & 359 & $390.0(+8.6)$ & $425.7(+18.56)$ & $445.6(+24.1)$ \\
\hline RCA-STD & 58 & $67.4(+16.46)$ & $71.50(+23.57)$ & $90.3(+56.0)$ \\
\hline RCA-MPI & 304 & $311(+2.3)$ & $350(+15.1)$ & $392(+29.0)$ \\
\hline RCA-HAD & 397 & $422(+11.3)$ & $484(+21.9)$ & $565(+42.3)$ \\
\hline RCA-ECE & 393 & $396(+0.76)$ & $412(+4.8)$ & $468(+19.1)$ \\
\hline RCA-GFDL & 351 & $367(+4.6)$ & $388(+10.5)$ & $456(+29.9)$ \\
\hline RCA-IPSL & 409 & & $498(+21.8)$ & $523(+27.9)$ \\
\hline RCA-CAN & 367 & & $4458(+21.3)$ & $447(+21.8)$ \\
\hline RCA-CNRM & 285 & & $317(+11.2)$ & $362(+27.0)$ \\
\hline RCA-MIROC & 262 & $264(+0.76)$ & $302(+15.3)$ & $276(+5.3)$ \\
\hline RCA-NORESM & 421 & $417(-0.91)$ & $457(+8.6)$ & $521(+23.8)$ \\
\hline
\end{tabular}

Table 3: Frequency expressed as number ARs detected in a 30 year period of different climate scenarios. The historical period is for all runs 1970-1999. Only for the ERAl runs it is 1979-2009. Numbers given in parenthesis denote relative change [\%] in the future period compared to the historical period.

Figure 4a compares the moisture transport by ARs over land which indicates the potential to force local heavy precipitation events. We note that the RCA-ERAI run has a lower moisture content over land compared to ERAI ( $5 \%$, Figure $4 \mathrm{a})$. This is in line with the models cold bias in air temperature

250 (Gröger et al., 2021a) which favors lower moisture contents. The probability distribution of diagnozed AR durations (Figure 4b) indicates no systematic differences between the ERA-I reanalysis, the hindcast run or the mean historical climate simulations. For all model realizations about half of the detected AR last for less than one day (Fig. 4). Noteworthy is the lower moisture content of nearly the entire RCA historical ensemble compared to the RCA-ERAI hindcast simulation. Overall, this points to a systematic negative bias in moisture contents over land in the RCA model. 
a)

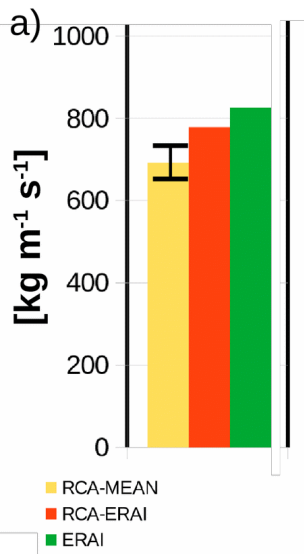

b) 40

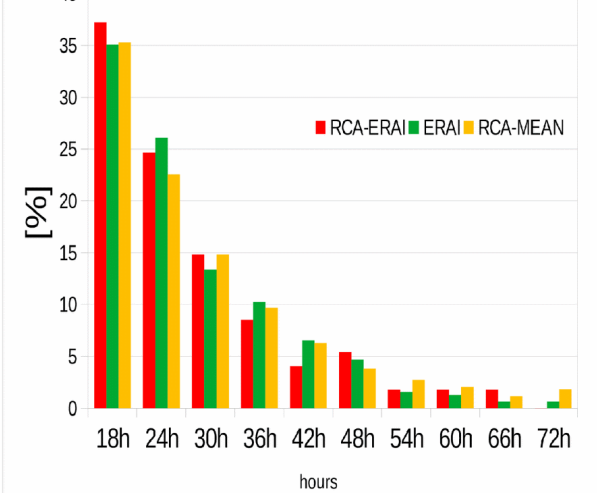

Figure 4: a) Average moisture transport over land by ARs for each model realization depicted from the climatological historical period (RCA-MEAN) as well as for the hindcast simulation (RCA-ERAI) and the reanlysis data set (ERAI). For RCA-MEAN the range of two standard deviations from individual realizations is given. b): Histogram of average durations of detected ARs.

\subsection{Impact on precipitation}

260 In a first step we estimate the likelihood for a certain region to be affected by an AR. As a simple index, we count the total number of days during which a land cell was covered by an AR (AR days, Figure 5a). As expected, ARs are most present over the UK and the coastal regions of western Europe. Further inland the AR imprint declines as ARs lose moisture due to rainfall and thus do not further meet the IVT threshold (Fig. 2). Strong moisture loss is also indicated along the Norwegian coast where the landfall of ARs cause strong rain events due to uplift.

Next we quantitatively evaluate the imprint of ARs on extreme precipitation by calculating the portion of yearly maximum of daily precipitation that is caused by ARs. The result is shown in Fig. $5 \mathrm{~b}$ which shows the percentage of yearly maximum daily precipitation rates forced by ARs. ARs explain up to $\sim 60 \%$ of the yearly maxima precipitation rates over southwestern Norway. A strong imprint is likewise seen over western UK and along the European coasts. 
a)
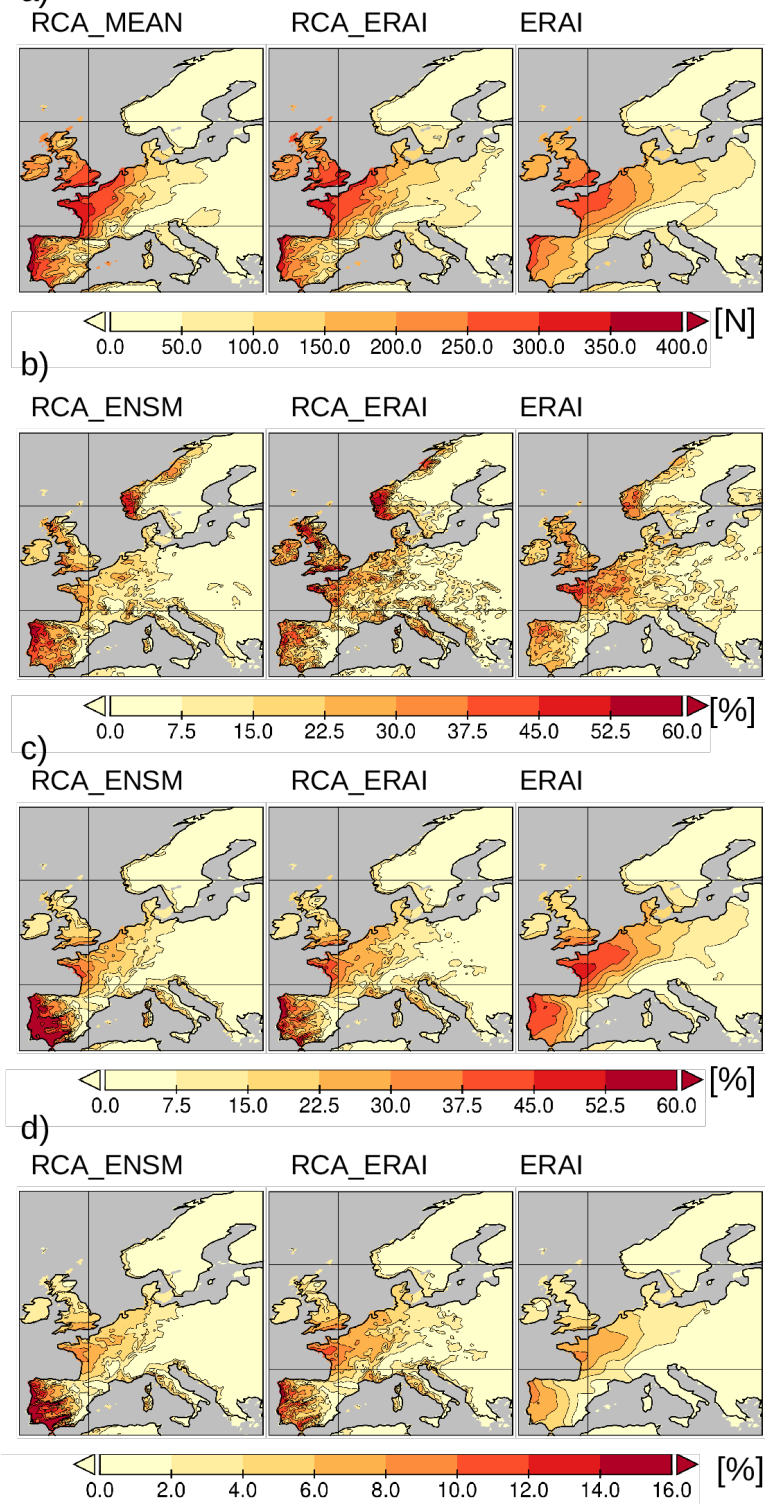

Figure 5: a) AR frequency expressed as total number of days grid cell was covered by an AR during the historical period. b) Percentage of annual maximum precipitation related to ARs .c) contribution of $A R$ forced precipitation to the $>95$ th percentile precipitation. d) same as $c$ ) but for the total precipitation

Besides their potential to force yearly precipitation maxima ARs strongly affect the fraction of heavy precipitation events. Here we investigate the AR contribution of precipitation to the total annual precipitation (Figure $5 \mathrm{~d}$ ) and to the fraction of heavy precipitation (Figure $5 \mathrm{c}$ ). The spatial pattern 
mainly resembles the pattern seen in the AR days (Figure $5 \mathrm{a}$ ) but further reflects the mean climatic conditions in Europe. In humid regions of central and western Europe, AR related rain contributes up to $40 \%$ (Bretagne) to the $>95$ th percentile precipitation. These are also the regions which are frequently affected by ARs (Fig. 5a). In semi-arid regions like the Iberian Peninsula the contribution increases to almost $60 \%$ which compares well with results from gridded reanalysis data sets (Lavers and Villarini, 2015). A considerable contribution is likewise seen along the western coast of

285 Italy. Here AR contribution is up to $30 \%$ (Fig. 5d) although ARs do not notably cause annual maximum precipitation rates (Fig. 5b). In the topographically elevated regions of Norway and over the Alps, i.e. regions supporting often strong convective rain events, the influence of ARs is also less pronounced. As expected in more humid regions of eastern Europe and Scandinavia ARs contribute only minor amounts to the annual total. A similar pattern is shown for the contribution to

290 the total annual precipitation (Figure 5d). Maxima contributions are seen over western France and the western Iberian Peninsula where ARs contribute up to $10 \%$ to the total precipitation.

\subsubsection{Comparison of the RCA ensemble mean with the ERAI hindcast and ERAI reanalysis}

295 In the historical simulations, i.e. when the model is forced by climate output the regional coupled models develop their own weather regimes which can not be expected to be in phase with recorded weather data. Therefore, individual AR incidences can be analyzed only statistically which is done in terms of calculated indices during the climatological historical period (Fig. 5). We now compare the results of the RCA historical ensemble mean (Figure 5, left column) with the

300 RCA-ERAI hindcast (Figure 5, middle column) and the ERAI reanalysis data Figure 5, right column) in which internal natural variability can be expected to reflect the observed weather. Figure 5 demonstrates that for most of the above described indices the RCA historical ensemble mean represents reasonably well the spatial pattern found in the RCA-ERAI simulation. The spatial correlation coefficients between RCA-ERAI and RCA-ENSM are respectively calculated as 0.98

305 for AR the frequency (Fig. 5a), 0.82 for the percentage of yearly maximum precipitation (Fig. 5b), and respectively 0.92 for contribution to total annual and heavy rain precipitation amount (Fig. $5 c, d)$.

Besides the spatial pattern seen in the AR indices, the detected ARs also undergo a strong

310 seasonal cycle. Figure 6 shows that ARs are most abundant during fall and early winter. A pronounced difference is, however, seen in August where the relative share is about twice as much in the RCA historical ensemble compared to the ERAI hindcast which implies that the AR season starts a bit too early in the RCA ensemble. However, all in all we find that spatial patterns and the seasonal cycle of ARs is well preserved in the models climate mode compared to the ERAI data

315 set and the ERAI hindcast. 


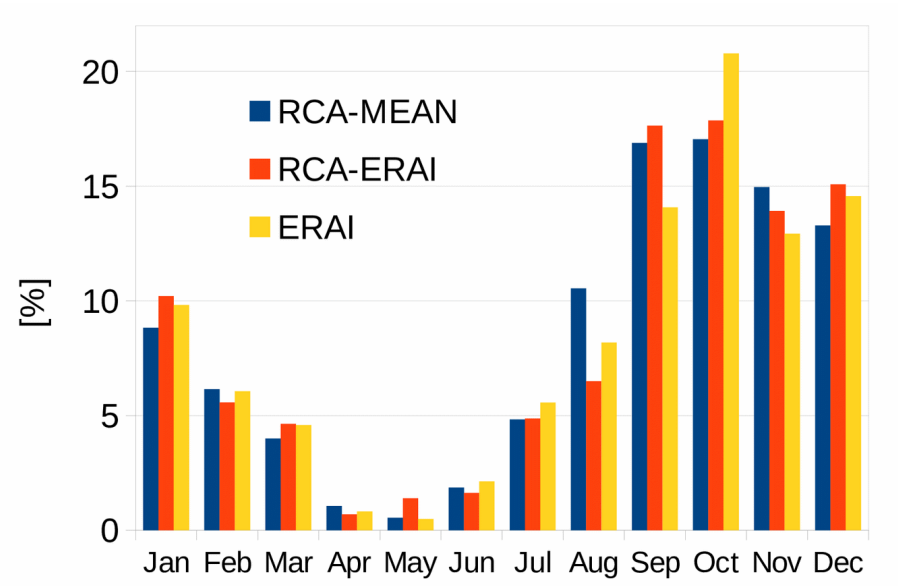

Figure 6: Seasonal cycle of detercted ARs expressed as precentage share of total number of detected AR. The reference period for the RCA historical ensemble (blue) is 1970-1999 and for the ERAl hindcast (orange) and ERAl (yellow) reanalysis it is 1979-2009.

\subsubsection{Effect of regionalization}

The above described spatial characteristics is also well reflected in the ERAI reanalysis data (Fig. 5, left column). However, the lower spatial resolution of this data set (approx. factor of 10, Table 1) destroys much of spatial variation which demonstrates the effect of the downscaling by RCA. This is more visible in the precipitation related indices (Fig. 5b-d) than in the AR frequencies (Fig. 5a). This is expected as precipitation patterns are modulated by stochastic processes and further modulated by topography while the integrated atmospheric moisture transports (used to detect and track ARs) are less affected by small scale patterns.

The added value of regionalization is demonstrated by the comparison between the high resolution RCA-ERAI run with a resolution of $0.22^{\circ}$ and the corresponding ERAI- data set with a resolution of $0.75^{\circ}$. First, the downscaled RCA-ERAI run shows notably higher AR frequencies and larger contribution to the total precipitation (and $>95^{\text {th }}$ percentile precipitation) along the coasts compared to the original ERAI data set (Fig. 5a,c,d). In turn, AR frequencies in the distal parts of eastern Europe are higher in the reanalysis data than in the ERA-I hindcast run. This implies ARs tend to penetrate less far inland after landfalling in the downscaled run. Apart from this, the downscaling effect is most pronounced in regions with elevated topography as well as in in semi aride climate zones of southern Europe. Over Iberia the RCA-ERAI run clearly resolves the distinct effect the of the west - east striking topographic features seen in the contributions to the precipitation budgets. They occur as small WSW-ENE striking bands of alternating high and lower AR precipitation following the topographic elements build up by the Sistema Central Plateau, the Sierra Morena mountains, and the Penibaetic orogenic system (Fig. 5c,d). Furthermore, the local maxima of AR contributions seen along Italy are by far less pronounced in the coarser ERAI reanalysis (Fig. 5c,d). Apart from this, we also find a notably lower amount of annual precipitation maxima related to ARs 
(Fig. 5b). Over Norway the difference can be as large as $15 \%$. Here, the lower resolution likely smooths heavy precipitation events.

Another slight but noteworthy RCA-ERAI vs ERAI difference is seen in the seasonal distribution of

350 ARs. In the RCA-ERAl hindcast the fall maximum is already registered in September while in ERAI it is recorded for October. The most likely explanation for this is a temperature bias introduced by RCA. Gröger et al., (2021a) showed that RCA has a negative temperature bias against the observational E-OBS data set. This means that air masses enter the lateral model boundary with a thermodynamically too high moisture load. The adaption, i.e. the loss of moisture when the air

355 masses are confronted which the mean thermodynamics state of the inner RCA-domain, probably takes longer for fast moving air masses like within ARs. This would favor the detection of too many ARs.

Finally, we note that the global CMIP5 models used to drive RCA have an even lower resolution ranging between $1.4^{\circ}(\mathrm{CNRM})$ and $3^{\circ}(\mathrm{CAN})$ which is notably lower than the ERAl reanalysis data set. This implies that the added value of regionalization in the future scenarios can be expected of even greater importance.

\section{Future climate change impact on ARs}

\subsection{General response of AR frequency and intensity}

365 Figure 7 summarizes the relative change in average moisture transport by ARs according to the different greenhouse gas scenarios and for each of the downscaled global models. Consistently, ARs become more intense i.e. they have a higher moisture load in a warmer climate. The intensity at the end of the century increases on average by 9\% (RCP2.6), 13\% (RCP4.5), and 24\% (RCP8.5) which is more or less in line with the corresponding increases of IVT thresholds (Fig. 2).

Besides intensity, also the frequencies of detected ARs increases (RCP2.6=8.6\%; RCP4.5=18.6\%, RCP8.5 $=24.1 \%$, Table 3) which are roughly proportional to the increase in intensity. However, not only the frequency of ARs increases but also the spread of the individual realizations at the end of the century. The relative change in ensemble spread (Table 3, 2nd row) increases even more than

375 the ensemble average (RCP2.6 $=16.5 \%$, RCP4.5 $=23.6 \%, \mathrm{RCP} 8.5=56.0 \%)$. This highlights the large uncertainty with respect to the chosen global model used for downscaling. Some advanced approaches for weighted model averaging were developed to reduce this type of uncertainties and have been tested for the case of AR over the US (Massoud et al., 2019; Massoud et al., 2020, Wootten et al., 2020). 


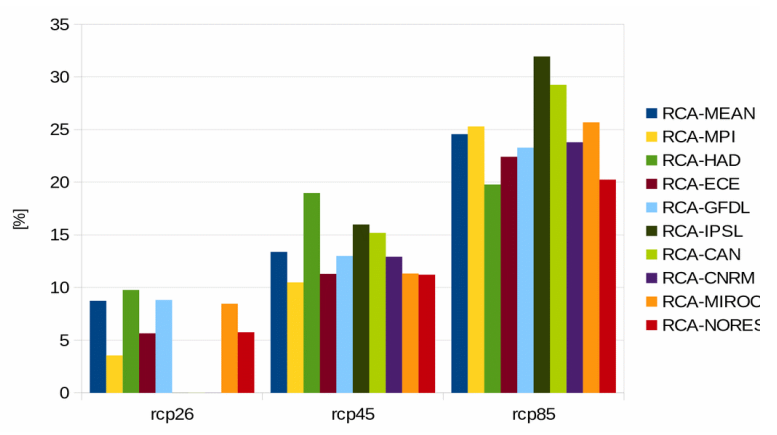

Figure 7: Relative change in moisture transport within ARs at the end of the century (20702099) compared to the historical period (1970-1999).

\subsection{Spatial changes}

Next we analyze spatial pattern changes in future AR imprint. First, AR frequencies are addressed. Figure 8 a demonstrates an overall increase in the frequency of AR days which is strongest over in the southwestern sector of the Atlantic (Biscay) and adjacent land areas with maximum response over western France and the southern UK. This pattern is more or less consistent across the RCP scenarios but differs in strengths ranging from $\sim+20 \%$ to more than $200 \%$ (Fig. 8a)

We now investigate how the increased AR frequencies influence precipitation patterns. In a first step the impact on the AR forced yearly maximum precipitation is addressed (Fig. 8b). The most robust change is the strong increase over the western central part of Europe which extends from western France along the coast of Belgium, the Netherlands northern Germany and Denmark up to the southern coast of Norway. Further spots of stronger AR impact are also visible along the northwestern tip of the Iberian Peninsula and the southern part of the UK. This general response is by far strongest in the unmitigated RCP8.5 scenario. In the moderate scenario RCP4.5 the

395 changes are less pronounced in eastern central Europe (Germany, Denmark). In the mitigation scenario RCP2.6 notable robust changes are restricted to a small area in NW France (Bretagne, Normandy). Over southern Scandinavia where the highest values are found during the historical period (see Fig. 5b) no robust changes are detected.

400 Next we address the number of AR forced heavy precipitation events. Figure $8 \mathrm{c}$ shows the number of events nearly everywhere increases. The strongest response is seen over southern Scandinavia where the relative increases exceed 300\%. Over the western European continent and the UK the average increases are in the range between $75-150 \%$ pointing to a roughly doubling risk for flooding. Apart from this very strong increases (>300\%) are noticed over eastern Europe (Figure 8c). Although in this region absolute AR occurrences are rather low, the strong relative increases indicate a further eastward propagation of AR under the warmer future climate compare to present day. 
a) RCP85 RCP45

RCP26

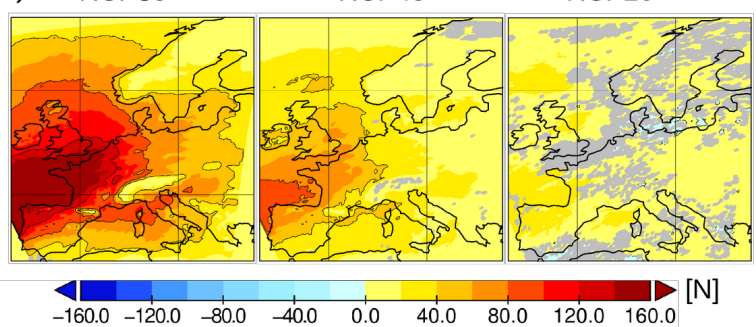

b)

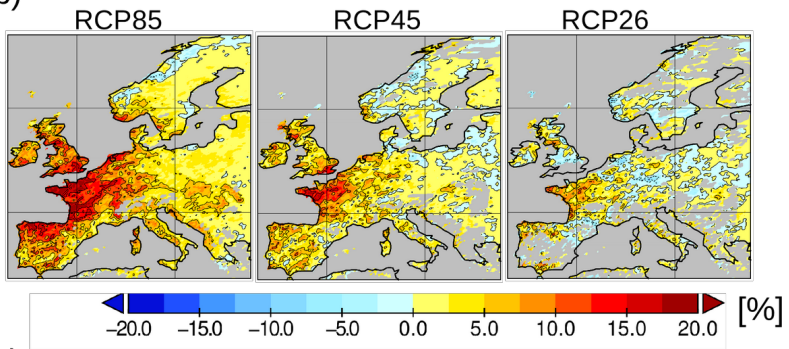

c)

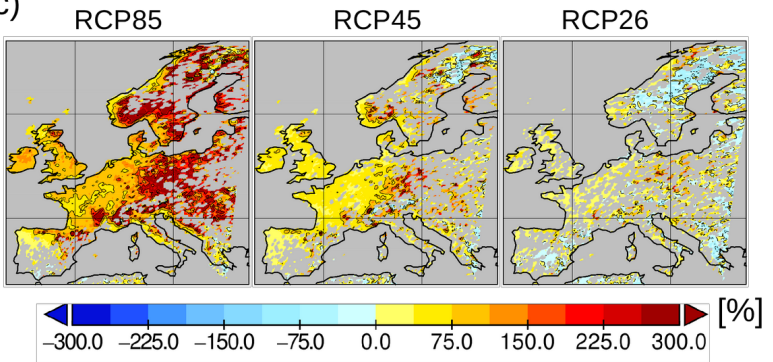

d) $\mathrm{RCP} 85$

RCP45

RCP26

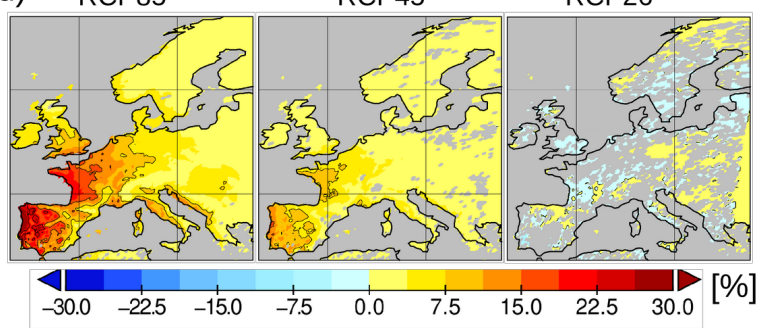

e) RCP85 RCP45 RCP26

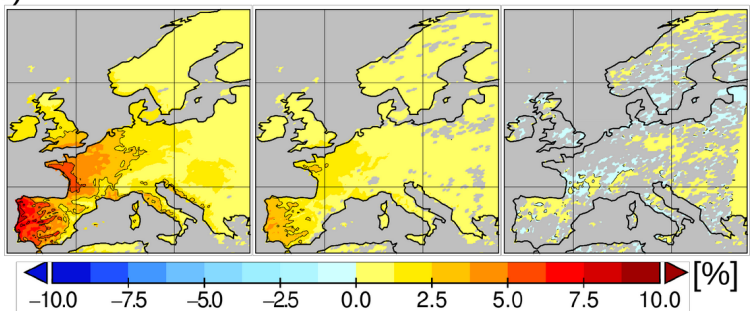

Figure 8: Difference between 2070-2099 minus 1970-1999 climatological indices for the RCA ensemble. a) AR days frequency b) AR forced yearly maximum precipitation rates. c) Number of $A R$ forced rain events within $>95$ th percentile fraction d) Change in the contribution of $A R$ forced precipitation to the heavy rain fraction (total $>95$ th percentile precipitation). e) same as $d$ ) but for the contribution to the annual total precipitation. Note all non-robust changes (at least $66 \%$ of downscaled runs agree on the sign of change) have been masked out. For b) - e) only changes over land are shown. 
The higher AR frequencies and moisture loads have also consequences for the local precipitation budget. Figures 8 displays the changes in the contribution of ARs to the heavy precipitation fraction (Fig. 8d) and the total annual precipitation (Fig. 8e). Most pronounced changes are seen in regions where already under historical climate condition large contributions are seen (Fig. 5c,d). Strongest increases are primarily seen over Iberia with changes up to $+30 \%$ to the heavy rain precipitation and up to $20 \%$ along the French coast (Bay of Biscay) compared to the historical period.

At least for the moderate and high greenhouse gas scenarios RCP4.5 and RCP8.5 the contributionanomalies are robustly positive (Fig. 8d,e). The positive anomalies imply that in these regions the AR induced precipitation rates increase stronger than mean precipitation rates.

The different response of mean precipitation and AR induced precipitation to climate change is depicted in Figure 9. The climatological mean change (Figure 9a) shows the typical change in precipitation over Europe pointing to dryer conditions over southern Europe and wetter conditions over northern Europe (e.g. Jacobs et al., 2014; Kjellström et al., 2018; Teichmann et al., 2018; Gröger et al., 2020a; Christensen et al., 2021). Hence, mean precipitation rates increase only slightly by up to maximal $12 \%$ over central Europe or even decrease over southern Europe. By contrast, AR induced precipitation increases between $\sim 25-40 \%$ over central Europe (Fig. 9b). In fact AR induced precipitation ranges are in most regions equally high as mean winter precipitation changes (not shown), i.e. the season where mean changes are highest. Also decreasing AR precipitation is found in southern Europe but the reductions are less strong compared to mean rates. The only exception is Norway where in fact AR induced precipitation decreases while mean rates increase. This likewise explains the low response of annual maximum changes (Fig. 8b).

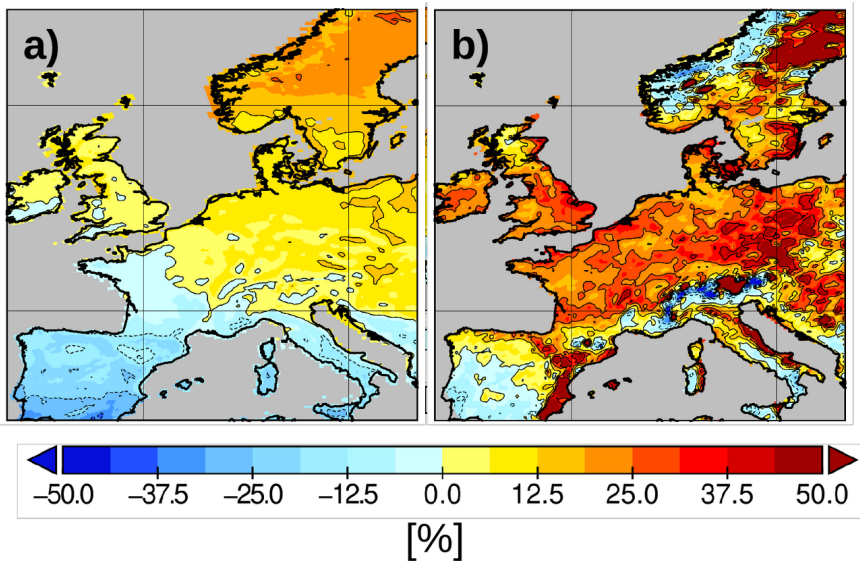

Figure 9: a) Relative change in mean precipitation rates for RCP85. b) Relative change in $A R$ induced precipitation rates. 


\subsection{Influence of potential dynamical changes}

440 In the mid to high latitudes it has been found, that climate changes in mean and extreme precipitation takes place at similar magnitudes and mainly reflect thermodynamical processes (i.e. increasing water carrying capacity with warming air, e.g. Emori and Brown, 2005). Exceptions from this occur only when large scale circulation changes with further impact on moisture transport are involved (Emori and Brown, 2005). Based on global CMIP5 models Gao et al. (2016) suggest that thermodynamics is also the main driver AR related precipitation changes but may be modulated by dynamical circulation changes due to changes in the Jet position.

a)

b)

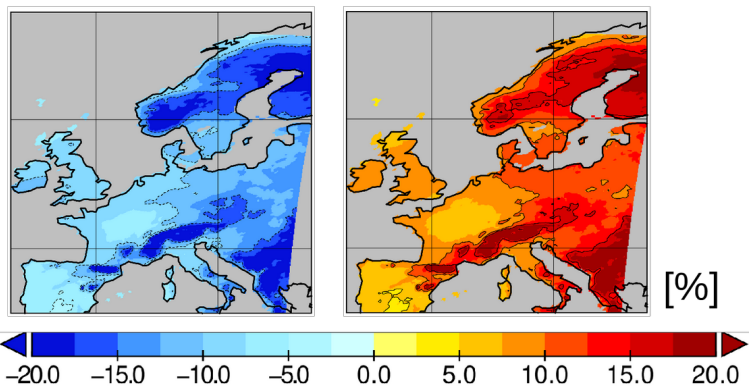

Figure 10: Analysis of AR origin in the RCA ensemble. a) Relative contribution of regional $A R$ occurences originating from the Atlantic north of $60^{\circ} \mathrm{N}$. b) same as a but for ARs originating from south of $45^{\circ} \mathrm{N}$. Shown is the change for RCP8.5 (2070 - 2099 minus 1970-1999).

In order to investigate potential dynamical changes we now elaborate more about the pathway of ARs on the their way from the open ocean to the continent. It is not feasible to analyze the movement of every single AR over time. Instead, we here perform a simple analysis to determine the AR source region for every AR. Hence we check for every AR incident registered on land at which latitude the AR entered the European sector along $10^{\circ} \mathrm{W}$ meridian. We here consider the latitudinal bins south of $45^{\circ} \mathrm{N}, 45-60^{\circ} \mathrm{N}$, and north of $60^{\circ} \mathrm{N}$. From this statistic we calculated for every land cell the percentage share of AR incidents for every latitudinal band (so that the sum of all bins at every land point sums up to $100 \%)$. The analysis is done for high emission greenhouse gas scenario RCP8.5 compared to the historical period.

Figure 10 shows the change in the relative contribution for the latitudes south of $45^{\circ} \mathrm{N}$ (Fig. 10a) and north of $60^{\circ} \mathrm{N}$ (Fig. 10b). Overall, the RCA ensemble clearly shows a relative increase of those ARs originating south of $45^{\circ} \mathrm{N}$ degree (Fig. 10a). Most prominent increases are seen over the Alpine region and Scandinavia whereas western and central Europe are less affected. Between 45 and 60 ${ }^{\circ} \mathrm{N}$ the changes are everywhere below $5 \%$ (not shown) indicating a more or less unchanged contribution within this latitudinal band.

465 By contrast, AR contributions from $>60^{\circ} \mathrm{N}$ are diminished (Fig. 10b). Over Scandinavia ARs from $>60^{\circ} \mathrm{N}$ contribute around $70-90 \%$ to the total AR events during the historical period (not shown). This contribution is reduced by $\sim 20 \%$ in RCP8.5 (Fig.10b) and thus likely explains the aforementioned 
dereased AR precipitation rates (Fig. 9b). Hence, for Scandinavia this implies a profound southward shift in the origin of ARs that cross Scandinavia. In turn, this shift suggests that the moisture has to be transported over a longer distance across the central continent compared to those ARs originating from $>60^{\circ} \mathrm{N}$.

In summary, we can conclude that ARs from the southern Atlantic sectors are more present over most land regions in a warmer climate. By contrast, ARs arriving from the northern sectors of the Atlantic are relative diminished over land (Fig. 10b).

\section{Discussion}

\subsection{Uncertainties with respect to the global driving CMIP5 models}

We now investigate individual ensemble members for a selected set of indices, namely, the changes in AR days frequency, the annual maximum precipitation, and the contribution of ARs to the yearly total heavy precipitation.

Figure 11a depicts the frequency of ARs. All realizations exhibit a highly coherent spatial pattern which is similar RCA ensemble mean (Fig. 8a) indicating the latter as a representative indicator for the bulk response. The model spread as summarized by the ensemble standard deviation asserts highest uncertainties in two latitudinal bands north of $40^{\circ} \mathrm{N}$ and north of $55^{\circ} \mathrm{N}$ in the North Atlantic. A notably strong increase over the North Atlantic is registered for the RCA realizations for RCA-HAD, RCA-IPSL, and RCA-MPI while RCA-MIROC and RCA-ECE show a particularly weak signal. RCAECE show a distinct separation into a northern and southern core zone of increased AR presence. Notably, one realization shows wider areas of decreased AR presence in the high latitude Atlantic (RCA-MIROC).

The response of AR forced annual maximum precipitation events is shown in Figure 11b. No clear consistent response is registered over the topographic elevated region of western Norway i.e. the region which is most impacted by ARs in the historical climate (Fig. 5b). Some models show distinct locations with decreased AR impact over Norway (e.g. RCA-MPI RCA-GFDL, RCA-IPSL) which is probably linked to the aforementioned decrease of ARs arising from $>60^{\circ} \mathrm{N}$. The most coherent change across the realizations is the more or less strong increase over the western France which in some realizations extends further to the east. However, also in this region local ensemble variability is pronounced and in RCA-ECE even a decrease is seen. The pronounced ensemble variability is not unexpected because the yearly maxima represent the most heavy precipitation events over a certain region.

Uncertainties with respect to the contribution to the heavy precipitation budget is highest in the region of largest changes (Fig. 11c). High inter-model variance is found for the southern tip of Iberia indicated by maximal standard deviations. In this region the contribution can either be reduced as in RCA-HAD or increased as high as $+50 \%$ as in RCA-CNRM. The same change pattern is likewise seen in Italy but with a lower magnitude. Higher uncertainties are likewise found for central Europe (France, Belgium, Netherlands, Germany). This mainly reflects the different inland penetration of ARs in the models response to climate change. In case of RCA-MIROC and RCA-ECE this results in only 
very low change $(<5 \%)$ for wide regions of France and Germany. With respect to the UK only one model RCA-HAD shows notable reductions of AR contributions over the UK.
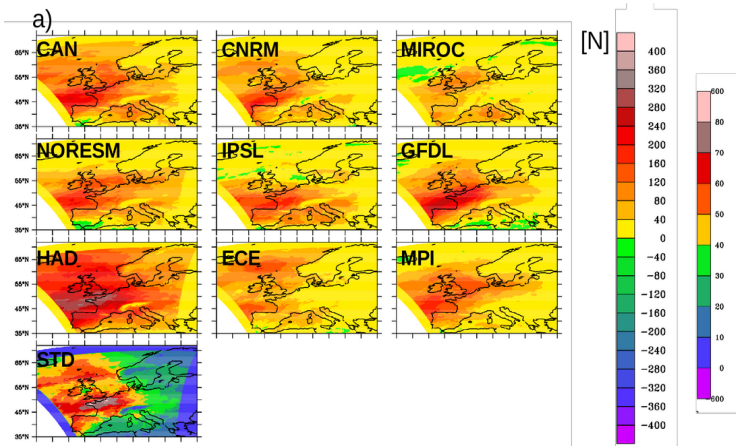

b)

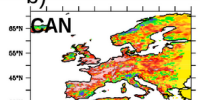

NORESM

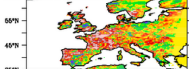

(2)

HAD.

- -5

$30 \mathrm{-1}-$

STD.

and
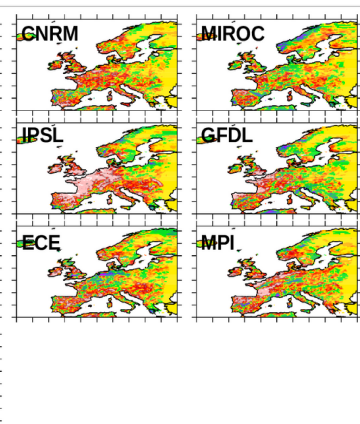

[\%]

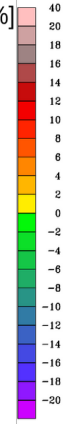

C)

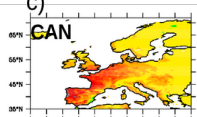

NORESM

$10 \mathrm{w}-$

HAD $H$. S?

w. 5.3

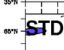
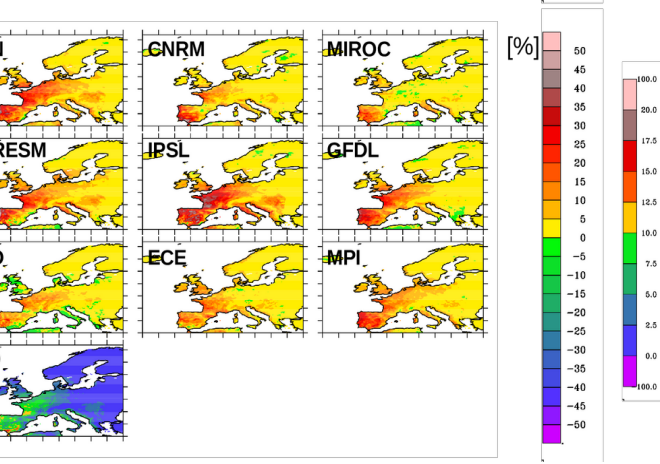

Figure 11: Change in frequency (2070-2099 minus 1970-1999). b) same as a) but for percentage in AR forced yearly maximum precipitation., c) same as a) but for AR contribution to heavy precipitation events (>95th percentile). Note the RCA realization are denoted by their foricing global model simply.STD denotes the inter-model standard deviation. Long bars indicate the color scale of the ensemble member indices. Short bar is for inter-model standard deviation)

In summary we can conclude that the ensemble members robustly agree on a stronger future AR

515 impact on heavy precipitation over western central Europe with a hot spot over NW France and further extension eastward depending on the realization. 


\subsection{Differences to global projections}

Our results generally agree with results from global CMIP5 models (e.g. Gao et al., Lavers et al., 2016; 2016; Ramos et al., 2016) that ARs become more frequent and intense. With respect to

520 previous studies we note that the climate change effect on AR frequency strongly depends on the chosen reference period. Studies that employ the $85^{\text {th }}$ percentile threshold derived from the historical period likewise for the future period often find a doubling of AR frequency (e.g. Lavers et al., 2013, Ramos et al., 2016). However, we here calculated separate $85^{\text {th }}$ percentile thresholds distinctively for historical and future periods. This was done because the 85th percentile threshold as suggested by

525 Lavers et al. (2012) represents the median IVT value within observed ARs during the historical period (Neiman et al., 2008). Consequently, the AR frequency increase found in this study is lower (as IVT thresholds for the future period are higher, Fig. 2) than in the aforementioned studies but still amount to $+20-30 \%$ increase across the models.

530 Main differences to global projections arise over Norway and the Iberian Peninsula, i.e. two hotspots of AR impact in Europe. Over Iberia the distribution of AR related heavy precipitation is clearly modulated by topographic structures, like the Sistema Central Plateau, the Sierra Morena mountains, and the Penibaetic orogenic system. These valleys and ridges lead to zonal bands of high and low increases of AR precipitation over Iberia in the future. Furthermore, our regional ensemble does not

535 indicate a robust climate change signal over Norway. Global CMIP5 models indicate for this region an increase of 10 to $20 \%$ in the AR contribution to heavy precipitation events in RCP8.5 (Gao et al.,2016, Fig. 9. therein). In contrast to this, the downscaled ensemble indicates only a weak and not robust response over Norway. The change in the AR precentage of annual maximum preciptation can be negative or positive depending on the global model and thus does not indicate a clear signal (Fig

540 11b). Likewise, the contribution to heavy precipitation is in all regional ensemble members below $5 \%$ with the exception of the southwestern top of Norway(Fig 11c).

Our finding that ARs from south of $45^{\circ} \mathrm{N}$ have an increased presence over Europe in the future high emission scenario points to larger scale atmospheric circulation changes. Such change could be

545 related to changes in the low level Jet stream (Gao et al., 2016) and/or indicate systematic changes in regional weather systems (Pasquier et a., 2018). At least in the southern Hemisphere a poleward shift of ARs has been reported for the recent decades (Ma et al., 2020). The authors suggested internal variations of basin scale sea surface temperatures as likely reasons.

\section{Summary and Conclusions}

A high resolution regional climate model with a resolution of $0.22^{\circ}$ was applied to investigate the impact of ARs on Europe. The added value of regionalization was analyzed by a hindcast run to downscale the ERA-Interim reanalysis data set with a resolution $0.75^{\circ}$. The added value is most obvious in topographic elevated areas and in the semi arid climate zone of southern Europe (Iberia,

555 Italy). In the central and southern part of the Iberian Peninsula the contribution to the regional precipitation budget is strongly modulated by E-W striking topographic signatures. This feature is not seen in ERA-I reanalysis data which shows on the contrary N-S striking gradients with highest precipitation in the west. Generally the AR imprint on analyzed indices in the ERAI data set is lower near the western European coasts but more visible in the distal parts of eastern Europe. This 
The regional climate model is further used to investigate the dynamics of ARs in present and future climate. For this in an ensemble of in total 34 simulations was carried to downscale global climate model scenarios from the CMIP5 suite with a coarse resolution between $1.4-3^{\circ}$. The models were used to downscale three greenhouse gas scenarios (RCP2.6, RCP4.5, and RCP8.5).

The historical simulations from the regional climate model ensemble are in good agreement with global ERAI reanalysis data set and an ERA-I simulation hindcast run. The regional climate ensemble shows strongest AR impact along near-coastal regions explaining up to $60 \%$ of yearly maximum precipitation rates in regions with orographic uplift (e.g. Norway). In regions with coastlines exposed to the North Atlantic but unaffected of orographic uplift AR related rain events constitute a significant contribution to the total annual yearly rain rate. Here the impact is largest in semi-arid regions of the Iberian Peninsula and along western Italy.

575 Our results show ARs become more frequent and have a higher moisture load in a future warmer climate (e.g. Lavers et al., 2013; Warner et al., 2015; Gao et al., 2016; Shields and Kiehl, 2016; Ramos et al., 2016; Shields et al., 2019; Massoud et al., 2019; Massoud et al., 2020; Whan et al., 2020). The potential of ARs to force annual maximum precipitation events increases most prominently over western France (Brittany) and northernmost Spain by up to $20 \%$ (RCP8.5). No robust ensemble response was found over Norway.

Our regional high resolution model allows a spatially more accurate calculation of AR contributions to the local water budget than possible with global earth system models. Over the Iberian Peninsula and western France the contribution of AR forced rain to the total annual precipitation increases by up to

$58510 \%$ as well as it does with respect to the total annual precipitation that falls as heavy precipitation (up to $+30 \%$ ). Furthermore, the well known dryer mean climate conditions in southern Europe (e.g. Jacob et al., 2014; Kjellström et al., 2018; Gröger et al., 2021a; Christensen et al., 2021) at the end of the century favors a more important role of ARs in the future climate as AR precipitation rates increase stronger than mean precipitation rates. The increased AR contribution found for the Iberian Peninsula

590 under contemporaneous climate drying is likely to influence the ground water recharge which is essential for maintaining ecosystem services and supporting agriculture in this area (e.g. MartosRosillo et al., 2015).

In particular for northern Europe we find a more southern position in the origin of ARs in the future 595 warmer climate compared to the historical period. In turn, this likely affects the path of ARs before arriving Scandinavia as moisture travels over a longer distance over land. This leads to locally decreased precipitation rates over Norway in RCP8.5.

Our study clearly demonstrates a larger imprint of ARs in Europe on the regional scale and a more dominant role of forcing heavy precipitation events with potential risk for flooding under the higher greenhouse gas scenarios RCP4.5 and RCP8.5. However, under the assumption of the greenhouse gas scenario RCP2.6 most of the climate induced changes are not robust which points to the potential benefit of climate mitigation actions. 
605 Finally, the present assessment of AR dynamics in regional ensembles for Europe must be considered as a first step since the realized horizontal resolution is still coarse $(24 \mathrm{~km})$ and not explicitly resolves convection. The future trends in regional high resolution modelling will allow resolutions of only a few kilometers and convection permitting models will be applied (e.g. Giorgi, 2019; Jacob et al., 2020). This will allow a more thorough investigation of the processes mediating the response of ARs to climate change and their pathway across Europe.

Acknowledgements

The research presented in this study is part of the Baltic Earth program (Earth System Science for the Baltic Sea region, see http://www.baltic.earth. Regional climate scenario simulations have been

615 conducted on the Linux clusters Krypton, Bi, Triolith and Tetralith, all operated by the National Supercomputer Centre in Sweden (http://www.nsc.liu.se/). Resources on Triolith and Tetralith were funded by the Swedish National Infrastructure for Computing (SNIC) (grants SNIC 002/12-25, SNIC 2018/3-280 and SNIC 2019/3-356). The Swedish Civil Contingencies Agency (MSB) and the Swedish Research Council for Sustainable Development (FORMAS) have contributed funding through the HydroHazards project (MSB 2019-0651).

\section{Data availability declaration}

The datasets generated during and/or analyzed during the current study are available from the corresponding author on reasonable request.

\section{Competing interests}

The authors declare that they have no conflict of interest.

\section{Code/data availability}

Numerical model codes available from the respective literature and corresponding first author. Data to reproduce results presented in this study are available upon reasonable request.

References

Alfieri, L., Dottori, F., Betts, R., Salamon, P., Feyen, L. (2018), Multi-Model Projections of River Flood 635 Risk in Europe under Global Warming. Climate, 6, 6, doi:10.3390/cli6010006.

Alfieri, L., Bisselink, B., Dottori, F., Naumann, G., de Roo, A., Salamon, P., Wyser, K. and Feyen, L. (2017), Global projections of river flood risk in a warmer world. Earth's Future, 5: 171-182. https://doi.org/10.1002/2016EF000485

Ashley, .R. M., Balmforth, D.J., Saul, A.J., and Blanskby, J.D. (2005), Flooding in the future predicting climate change, risks and responses in urban areas. Water Sci Technol 1, 52 (5): 265-273. doi: https://doi.org/10.2166/wst.2005.0142

645 Cabos, W., de la Vara, A., Álvarez-García, F.J. et al. Impact of ocean-atmosphere coupling on regional climate: the Iberian Peninsula case. Clim Dyn 54, $4441-4467$ (2020). https://doi.org/10.1007/ s00382-020-05238-x

Champeaux, J.L., Masson, V. and Chauvin, F. (2005), ECOCLIMAP: a global database of land 
650 surface parameters at $1 \mathrm{~km}$ resolution. Met. Apps, 12: 29-32. https://doi.org/10.1017/S1350482705001519

Clarke L, Edmonds J, Jacoby H, Pitcher H, Reilly J, Richels R (2007) Scenarios of greenhouse gas emissions and atmospheric concentrations. Sub-report 2.1A of Synthesis and Assessment Product

6552.1 by the U.S. Climate Change Science Program and the Subcommittee on Global Change Research. Department of Energy, Office of Biological \& Environmental Research, Washington, 7 DC., USA, pp 154

Christensen, O.B., Kjellström, E., Dieterich, C., Gröger, M., Meier, H.E.M. (2021). Regional climate projections for the Baltic Sea Region until 2100, Earth System Dynamics, submitted.

Dacre, H. F., P. A. Clark, O. Martinez-Alvarado, M. A. Stringer, and D. A. Lavers (2015), How do atmospher ic rivers form?, Bull. Am. Meteorol. Soc., 96(8), 1243-1255, http://dx.doi.org/10.1175/BAMS-D-14-00031.1

Dettinger, M. D. (2011), Climate change, atmospheric rivers, and floods in California-A multimodel analysis of storm frequency and magnitude changes. Journal of the American Water Resources Association, 47(3), 514-523

670 Dettinger MD. 2013. Atmospheric rivers as drought busters on the U.S. West Coast. J. Hydrometeor. 14:1721-32, https://doi.org/10.1175/JHM-D-13-02.1

Dieterich, C., Wang, S., Schimanke, S., Gröger, M., Klein, B., Hordoir, R., Samuelsson, P., Liu, Y., Axell, L., Höglund, A., Meier, H.E.M. (2019a): Surface heat budget over the North Sea in climate

675 change simulations. Atmosphere, 10, 272. doi:10.3390/atmos10050272.

Dieterich, C. and Gröger, M. and Arneborg, L. and Andersson, H. C., 2019b. Extreme sea levels in the Baltic Sea under climate change scenarios -- Part 1: Model validation and sensitivity, Ocean Sci, 15, 6, 1399-1418, 10.5194/os-15-1399-2019

680

Di Luca, A., de Elía, R. \& Laprise, R. Potential for added value in precipitation simulated by highresolution nested Regional Climate Models and observations. Clim Dyn 38, 1229-1247 (2012). https://doi.org/10.1007/s00382-011-1068-3

685 Espinoza, V., Waliser, D. E., Guan, B., Lavers, D. A., \& Ralph, F. M. (2018). Global analysis of climate change projection effects on atmospheric rivers. Geophysical Research Letters, 45, 4299-4308. https://doi.org/10.1029/2017GL076968

Emori, S., and Brown, S. J. (2005), Dynamic and thermodynamic changes in mean and extreme

690 precipitation under changed climate, Geophys. Res. Lett., 32, L17706, doi:10.1029/2005GL023272 Feser F. , Rockel B. , von Storch H. , Winterfeldt J. , Zahn R. Regional climate models add value to global model data: a review and selected examples. Bull. Am. Meteorol. Soc. 2011; 92(9): 11811192. DOI: 10.1175/2011BAMS3061.1

695 Gao, Y., Lu, J., \& Leung, L. R. (2016), Uncertainties in Projecting Future Changes in Atmospheric Rivers and Their Impacts on Heavy Precipitation over Europe, Journal of Climate, 29(18), 6711-6726; DOI: https://doi.org/10.1175/JCLI-D-16-0088.1

Gimeno L, Nieto R, Vázquez M and Lavers DA (2014) Atmospheric rivers: a mini-review. Front. Earth 
Gimeno, L., Dominguez, F., Nieo, R., Trigo, R., Drumond, A., Reason, C. J.C., Taschetto, A.S., Ramos, A.M., Kumar, R., Marengo, J., (2016), Major Mechanisms of Atmospheric Moisture Transport and Their Role in Extreme Precipitation Events, Annual Review of Environment and Resources 2016 41:1, 117-141

Giorgi F (2019) Thirty years of regional climate modeling: Where are we and where are we going next? J Geophys Res 124:5696-5723. https://doi.org/10.1029/2018JD030094

Gröger, M., Dieterich, C., Meier, H.E.M., Schimanke, S., (2015) Thermal air-sea coupling in hindcast simulations for the North Sea and Baltic Sea on the NW European shelf, Tellus A: Dynamic Meteorology and Oceanography, 67:1, DOI: 10.3402/tellusa.v67.26911

Gröger, M., Arneborg, L., Dieterich, C., Höglund, A., and Meier, H.E.M. (2019), Summer hydrographic changes in the Baltic Sea, Kattegat and Skagerrak projected in an ensemble of climate scenarios downscaled with a coupled regional ocean-sea ice-atmosphere model. Clim Dyn 53, 5945-5966 doi:10.1007/s00382-019-04908-9

Gröger, M., Dieterich, C., Meier, H.E.M., (2021a), Is interactive air sea coupling relevant for simulating the future climate of Europe?, Climate Dynamics, doi: 10.1007/s00382-020-05489-8.

Gröger, M., Dieterich, C., Haapala, J., Ho-Hagemann, H. T. M., Hagemann, S., Jakacki, J., May, W., Meier, H. E. M., Miller, P. A., Rutgersson, A., and Wu, L. (2021b): Coupled regional Earth system modelling in the Baltic Sea region, Earth Syst. Dynam. Discuss. [preprint], https://doi.org/10.5194/esd2021-14, in review.

Guan, B., and Waliser, D. E. (2015), Detection of atmospheric rivers: Evaluation and application of an algorithm for global studies, J. Geophys. Res. Atmos., 120, 12514- 12535, doi:10.1002/2015JD024257

Hagemann, S., and L. Dümenil (1998), A parameterization of the lateral waterflow for the global scale, Clim. Dyn., 14, 17- 31

Hagemann, S., H. Göttel, D. Jacob, P. Lorenz, and E. Roeckner (2009), Improved regional scale 735 processes reflected in projected hydrological changes over large European catchments, Clim. Dyn., 32(6), 767- 781, doi:10.1007/s00382-008-0403-9

Harvey, B. J., Cook, P., Shaffrey, L. C., \& Schiemann, R. (2020). The response of the northern hemisphere storm tracks and jet streams to climate change in the CMIP3, CMIP5, and CMIP6 climate

740 models. Journal of Geophysical Research: Atmospheres, 125, e2020JD032701. https://doi.org/10.1029/2020JD032701

Held IM, Soden BJ (2006) Robust responses of the hydrological cycle to global warming. J Clim 19(21):5686-5699, https://doi.org/10.1175/JCLI3990.1.

Ho-Hagemann, H.T.M., Gröger, M., Rockel, B., Zahn, M., Geyer, B., Meier, H.E.M. (2017): Effects of air-sea coupling over the North Sea and the Baltic Sea on simulated summer precipitation over Central Europe. Climate Dyn., pp. 1-26. doi:10.1007/s00382-017-3546-8. 
750 Huang, X., Swain, D.L., and Hall, A.D., 2020, Future precipitation increase from very high resolution ensemble downscaling of extreme atmospheric river storms in California, Science, 6, (29), doi: 10.1126/sciadv.aba1323

Jacob, D. (2001), A note to the simulation of the annual and interannual variability of the water budget over the Baltic Sea drainage basin, Meteorol. Atmos. Phys., 77(1-4), 61- 73

Jacob, D., Petersen, J., Eggert, B. et al. EURO-CORDEX (2014): new high-resolution climate change projections for European impact research. Reg Environ Change 14, 563-578. https://doi.org/10.1007/ $\underline{\text { s10113-013-0499-2 }}$

Jacob D, Teichmann C, Sobolowski S et al (2020) Regional climate downscaling over Europe: perspectives from the EURO-CORDEX community. Reg Environ Change. https://doi.org/10.1007/s10113-020-01606-9.

765 Jeworrek J, Wu L, Dieterich C, Rutgersson A (2017) Characteristics of convective snow bands along the Swedish east coast. Earth Syst Dyn 8:163-175. https://doi.org/10.5194/esd-8-163-2017

Jungclaus, J. H., N. Fischer, H. Haak, K. Lohmann, J. Marotzke, D. Matei, U. Mikolajewicz, D. Notz, and J. S. von Storch (2013), Characteristics of the ocean simulations in MPIOM, the ocean

770 component of the MPI-Earth system model, J. Adv. Model. Earth Syst., 5, 422- 446, doi:10.1002/jame.20023

Kaiser-Weiss, A.K., Borsche, M., Niermann, D., Kaspar, F., Lussana, C., Isotta, F.A., van den Besselaar, E., van der Schrier, G., and Unden, P., (2019), Added value of regional reanalyses for

775 climatological applications, Environ. Res. Commun. https://doi.org/10.1088/2515-7620/ab2ec3

Kelemen, F.D., Primo, C., Feldmann, H., Ahrens, B. (2019), Added Value of Atmosphere-Ocean Coupling in a Century-Long Regional Climate Simulation, Atmosphere, 10(9), 537,

https://doi.org/10.3390/atmos10090537.

Kjellström, E., Nikulin, G., Strandberg, G., Christensen, O. B., Jacob, D., Keuler, K., Lenderink, G., van Meijgaard, E., Schär, C., Somot, S., Sørland, S. L., Teichmann, C., and Vautard, R. (2018), European climate change at global mean temperature increases of 1.5 and $2{ }^{\circ} \mathrm{C}$ above pre-industrial conditions as simulated by the EURO-CORDEX regional climate models, Earth Syst. Dyn., 9, 459478, https://doi.org/10.5194/esd-9-459-2018.

Kousky C (2014) Informing climate adaptation: a review of the economic costs of natural disasters. Energy Econ 46:576-592, https://doi.org/10.1016/j.eneco.2013.09.029.

790 Kupiainen M. , Jansson C., Samuelsson P. , Jones C. , Willén U. , co-authors . Rossby Centre regional atmospheric model, RCA4, Rossby Center News Letter. 2014. Online at: http://www.smhi.se/ en/Research/Research-departments/climate-research-rossby-centre2-552/1.16562 .

Lavers, D. A., R. P. Allan, E. F. Wood, G. Villarini, D. J. Brayshaw, and A. J. Wade (2011), Winter

795 floods in Britain are connected to atmospheric rivers, Geophys. Res. Lett., 38, L23803, doi:10.1029/2011GL049783 
Lavers, D. A., G. Villarini, R. P. Allan, E. F. Wood, and A. J. Wade (2012), The detection of atmospheric rivers inatmospheric reanalyses and their links to British winter floods and the large-scale climatic circulation, J. Geophys. Res., 117,D20106, doi:10.1029/2012JD018027

Lavers, D. A., and Villarini, G. (2013), The nexus between atmospheric rivers and extreme precipitation across Europe, Geophys. Res. Lett., 40, 3259-3264, doi:10.1002/grl.50636

805 Lavers, D. A. \& Villarini, G. (2015), The contribution of atmospheric rivers to precipitation in Europe and the United States. J. Hydrol. 522, 382-390.

Lavers, D. A., Allan, R.P., Villarini, G., Lloyd-Hughes, B., Brayshaw, D.J., Wade, A.J., (2013), Future changes in atmospheric rivers and their implications for winter flooding in Britain, Environ. Res. Lett. 8, 034010, DOI: 10.1088/1748-9326/8/3/034010

Lavers, D. A., R. P. Allan, E. F. Wood, G. Villarini, D. J. Brayshaw, and A. J. Wade (2011), Winter floods in Britain are connected to atmospheric rivers, Geophys. Res. Lett., 38, L23803, doi:10.1029/2011GL049783.

Lavers, D. A., Ralph, F. M., Waliser, D. E., Gershunov, A., and Dettinger, M. D. (2015), Climate change intensification of horizontal water vapor transport in CMIP5, Geophys. Res. Lett., 42, 56175625, doi:10.1002/2015GL064672

820 Ma, W., Chen, G., \& Guan, B. (2020). Poleward shift of atmospheric rivers in the Southern Hemisphere in recent decades. Geophysical Research Letters, 47, e2020GL089934. https://doi.org/10.1029/2020GL089934

Madec G, The NEMO Team (2012) "NEMO ocean engine”: Note du Pole de modélisation de l'Institut Pierre-Simon Laplace, France, No 27, ISSN no 1288-1619

Marsland, S. J., H. Haak, J. H. Jungclaus, M. Latif, and F. Roeske (2002), The Max-Planck-Institute global ocean/sea ice model with orthogonal curvilinear coordinates, Ocean Modell., 5(2), 91- 126

830 Martos-Rosillo, S., González-Ramón, A., Jiménez-Gavilán, P. et al. Review on groundwater recharge in carbonate aquifers from SW Mediterranean (Betic Cordillera, S Spain). Environ Earth Sci 74, 7571 7581 (2015). https://doi.org/10.1007/s12665-015-4673-3

Massoud, E.; Massoud, T.; Guan, B.; Sengupta, A.; Espinoza, V.; De Luna, M.; Raymond, C. (2020);

835 Waliser, D. Atmospheric Rivers and Precipitation in the Middle East and North Africa (MENA). Water, 12, 2863. https://doi.org/10.3390/w12102863

Massoud, E. C., Espinoza, V., Guan, B., \& Waliser, D. E. (2019). Global Climate Model Ensemble Approaches for Future Projections of Atmospheric Rivers. Earth's Future, 7: 1136- 11511151. https:// 840 doi.org/10.1029/2019EF001249

Nayak, M. A., and Villarini, G. (2017), A long-term perspective of the hydroclimatological impacts of atmospheric rivers over the central United States, Water Resour. Res., 53, 1144-1166, doi:10.1002/2016WR019033 
Nayak, M. A., G. Villarini, and D. A. Lavers (2014), On the skill of numerical weather prediction 4362, doi:10.1002/2014GL060299

Neiman, P. J., , F. M. Ralph, , G. A. Wick, , J. D. Lundquist, , and M. D. Dettinger, 2008: Meteorological characteristics and overland precipitation impacts of atmospheric rivers affecting the

855 west coast of North America based on eight years of SSM/I satellite observations. J. Hydrometeor., 9, 22-47, doi:10.1175/2007JHM855.1.

Neiman, P. J., L. J. Schick, F. M. Ralph, M. Hughes, and G. A. Wick (2011), Flooding in Western Washington: The connection to atmospheric rivers, J. Hydrometeorol., 12(6), 1337-1358

O'Brien, T. A., Payne, A. E., Shields, C. A., Rutz, J., Brands, S., Castellano, C., Chen, J., Cleveland, W., DeFlorio, M. J., Goldenson, N., Gorodetskaya, I. V., Díaz, H. I., Kashinath, K., Kawzenuk, B., Kim, S., Krinitskiy, M., Lora, J. M., McClenny, B., Michaelis, A., O’Brien, J. P., Patricola, C. M., Ramos, A. M., Shearer, E. J., Tung, W., Ullrich, P. A., Wehner, M. F., Yang, K., Zhang, R., Zhang, Z., \& Zhou, Y.

865 (2020). Detection Uncertainty Matters for Understanding Atmospheric Rivers, Bulletin of the American Meteorological Society, 101(6), E790-E796

Pasquier, J. T., Pfahl, S., \& Grams, C. M. (2019). Modulation of atmospheric river occurrence and associated precipitation extremes in the North Atlantic Region by European weather regimes.

Geophysical Research Letters, 46, 1014- 1023. https://doi.org/10.1029/2018GL081194

Payne, A.E., Demory, ME., Leung, L.R. et al. (2020), Responses and impacts of atmospheric rivers to climate change. Nat Rev Earth Environ 1, 143-157, https://doi.org/10.1038/s43017-020-0030-5

875 Primo, C., Kelemen, F. D., Feldmann, H., Ahrens, B. (2019): A regional atmosphere-ocean climate system model (CCLMv5.0clm7-NEMOv3.3-NEMOv3.6) over Europe including three marginal seas: on its stability and performance, Geoscientific Model Development Discussions, 2019, 1-33, doi: 10.5194/gmd-2019-73

880 Ralph, F. M., P. J. Neiman, G. A. Wick, S. I. Gutman, M. D. Dettinger, D. R. Cayan, and A. B. White (2006), Flooding on California's Russian River: Role of atmospheric rivers, Geophys. Res. Lett., 33, L13801, doi:10.1029/2006GL026689.

Ralph FM, Dettinger MD. 2011. Storms, floods, and the science of atmospheric rivers. EOS 92(32):265-66

Ralph, F. M., and M. D. Dettinger (2012), Historical and national perspectives on extreme West Coast precipitation associated with atmospheric rivers during December 2010, Bull. Am. Meteorol. Soc., 93, 783-790, doi:10.1175/BAMS-D-11-00188.1.

Ramos AM, Trigo RM, Liberato MLR, Tomé R. 2015a Daily precipitation extreme events in the Iberian Peninsula and its association with atmospheric rivers. J. Hydrometeor. 16:579-97

Ramos, A. M., Nieto, R., Tomé, R., Gimeno, L., Trigo, R. M., Liberato, M. L. R., and Lavers, D. A

895 (2016): Atmospheric rivers moisture sources from a Lagrangian perspective, Earth Syst. Dynam., 7, 371-384, https://doi.org/10.5194/esd-7-371-2016, 
Ramos, A. M., R. Tomé, R. M. Trigo, M. L. R. Liberato, and J. G. Pinto (2016), Projected changes in atmospheric rivers affecting Europe in CMIP5 models, Geophys. Res. Lett., 43, 9315-9323, doi:10.1002/2016GL070634

Riahi K, Gruebler A, Nakicenovic N (2007) Scenarios of long-term socio-economic and environmental development under climate stabilization. Technol Forecast Soc Chang 74(7):887-935

905 Riahi K, Rao S, Krey V et al (2011) RCP 8.5-a scenario of comparatively high greenhouse gas emissions. Clim Change 109:33. https://doi.org/10.1007/s10584-011-0149-y

Samuelsson P, Jones CG, Willen U, Ullerstig A, Golvig S, Hansson U, Jansson C, Kjellström E, Nikulin G, Wyser K (2011) The Rossby Centre Regional Climate model RCA3: model description and performance. Tellus A 63:4-23. https://doi.org/10.1111/j.1600-0870.2010.00478.x

Sayers, P.B; Horritt, M; Penning-Rowsell, E; McKenzie, A. (2015) Climate Change Risk Assessment 2017: Projections of future flood risk in the UK. Research undertaken by Sayers and Partners on behalf of the Committee on Climate Change. Published by Committee on Climate Change, London.

Schiemann, R., Vidale, P. L., Shaffrey, L. C., Johnson, S. J., Roberts, M. J., Demory, M.-E., Mizielinski, M. S., and Strachan, J. (2018): Mean and extreme precipitation over European river basins better simulated in a $25 \mathrm{~km}$ AGCM, Hydrol. Earth Syst. Sci., 22, 3933-3950, https://doi.org/10.5194/hess-22-3933-2018.

920 Sein, D. V., Mikolajewicz, U., Gröger, M., Fast, I., Cabos, W., Pinto, J. G., et al. (2015). Regionally coupled atmosphere-ocean-sea ice-marine biogeochemistry model ROM: 1. description and validation. J. Adv. Model. Earth Syst. 7, 268-304. doi: 10.1002/2014ms000357

Sein, D.V, Gröger, M., Cabos, W., Alvarez, F., Hagemann, S., de la Vara, A., Pinto, J.G., Izquierdo,

925 A., Koldunov, N.V., Dvornikov, A. Y., Limareva, N., Martinez, B., Jacob, D. (2020), Regionally coupled atmosphere - ocean - marine biogeochemistry model ROM: 2. Studying the climate change signal in the North Atlantic and Europe J. Adv. Model. Earth Syst., https://doi.org/10.1029/2019MS001646.

Sodemann, H. \& Stohl, A. (2013), Moisture origin and meridional transport in atmospheric rivers and their association with multiple cyclones. Mon. Weather Rev. 141, 2850-2868

Soto-Navarro, J., Jordá, G., Amores, A. et al. Evolution of Mediterranean Sea water properties under climate change scenarios in the Med-CORDEX ensemble. Clim Dyn 54, 2135-2165 (2020). https://doi.org/10.1007/s00382-019-05105-4

Shields, C. A., and Kiehl, J. T. (2016), Atmospheric river landfall-latitude changes in future climate simulations, Geophys. Res. Lett., 43, 8775-8782, doi:10.1002/2016GL070470

Shields, C. A., Rosenbloom, N., Bates, S., Hannay, C., Hu, A., Payne, A. E., et al. (2019). Meridional 940 heat transport during atmospheric rivers in high-resolution CESM climate projections. Geophysical Research Letters, 46, 14702- 14712. https://doi.org/10.1029/2019GL085565

Taylor, K.E., Stouffer, R.J., and Meehl, G.A., (2012) An overview of CMIP5 and the experiment design. Bull Am Meteorol Soc 93:485-498

Valcke, S., A. Caubel, D. Declat, and L. Terray (2003), OASIS3 Ocean Atmosphere Sea Ice Soil 
User's Guide, Tech. Rep. TR/CMGC/03-69, CERFACS, Toulouse, France

Vancoppenolle, M., Fichefet, T., Goosse, H., Bouillon, S., Madec, G., and Morales Maqueda, M. A. (2008): Simulating the mass balance and salinity of Arctic and Antarctic sea ice. 1. Model description and validation, Ocean Modell., 27, 33-53, doi:10.1016/j.ocemod.2008.10.005.

van Haren, R., Haarsma, R. J., van Oldenborgh, G. J. \& Hazeleger, W. Resolution dependence of European precipitation in a state-of-the-art atmospheric general circulation model (2015), J. Clim. 28,

955 5134-5149.

van Vuuren D, den Elzen M, Lucas P, Eickhout B, Strengers B, van Ruijven B, Wonink S, van Houdt $R$ (2007) Stabilizing greenhouse gas concentrations at low levels: an assessment of reduction strategies and costs. Clim Change. https://doi.org/10.1007/s/10584-006-9172-9

van Vuuren DP, Stehfest E, den Elzen MGJ et al (2011) RCP2.6: exploring the possibility to keep global mean temperature increase below $2{ }^{\circ} \mathrm{C}$. Clim Change 109:95. https://doi.org/10.1007/s10584$\underline{011-0152-3}$

965 Wang S., Dieterich C., Döscher R., Höglund A., Hordoir R., Meier HEM, Samuelsson P., Schimanke S., (2015) Development and evaluation of a new regional coupled atmosphere-ocean model in the North Sea and Baltic Sea. Tellus A 67:1. https://doi.org/10.3402/tellusa.v67.24284

Wang X, Li J, Sun C, Liu T (2017) NAO and its relationship with the Northern Hemisphere mean

970 surface temperature in CMIP5 simulations. J Geophys Res Atmos 122:4202-4227. https://doi.org/10.1002/2016JD025979

Warner, M. D., C. F. Mass, and E. P. Salathe (2015), Changes in winter atmospheric rivers along the North American west coast in CMIP5 climate models, J. Hydrol. Meteorol., doi: 10.1175/JHM-D-140080.1

Whan, K., Sillmann, J., Schaller, N. et al. Future changes in atmospheric rivers and extreme precipitation in Norway. Clim Dyn 54, 2071-2084 (2020). https://doi.org/10.1007/s00382-019-05099-z

980 Wootten AM, Massoud EC, Sengupta A, Waliser DE, Lee H. The Effect of Statistical Downscaling on the Weighting of Multi-Model Ensembles of Precipitation. Climate. 2020; 8(12):138.

https://doi.org/10.3390/cli8120138

Zappa G, Shaffrey LC, Hodges KI (2013) The ability of CMIP5 models to simulate North Atlantic extratropical cyclones. J Clim 26(15):5379-5396

Zhu, Y., and Newell, R. (1998). A proposed algorithm for moisture fluxes from atmospheric rivers. Mon. Wea. Rev. 126, 725-735. doi: 10.1175/1520-0493(1998)126\%3C0725:APAFMF\%3E2.0.CO;2

990 Zhu, S., Remedio, A.R.C., Sein, D.V. et al. Added value of the regionally coupled model ROM in the East Asian summer monsoon modeling. Theor Appl Climatol 140, 375-387 (2020).

https://doi.org/10.1007/s00704-020-03093-8. 